\title{
オープンデータを用いた 定量的海岸景観評価手法に関する研究
}

\author{
市村 康 1 - 松原 雄平 2 -五島 幸太郎3 \\ 1正会員 日本ミクニヤ株式会社 大阪支店長（テ556-0021大阪府大阪市浪速区幸町3-1-10） \\ E-mail:ichimura@mikuniya.co.jp \\ 2正会員鳥取大学大学院教授 工学研究科教授（干680-8552 鳥取県鳥取市湖山町南4-101） \\ E-mail:matubara@cv.tottori-u.ac.jp \\ 3日本ミクニヤ株式会社グループリーダー（テ556-0021大阪府大阪市浪速区幸町3-1-10) \\ E-mail:ko-goto@mikuniya.co.jp
}

\begin{abstract}
本研究では，オープンデータを用い，鳥取県景観マップを作成し，海岸景観形成ガイドラインに従い， 景観構成指標を自然環境基盤, 生態環境, 生活環境の 3 つの視座に分類される景観構成指標から景観指標 を求めた，次に，筆者らが開発した景観感性設計システムと合わせて分析を行い，同評価方法の有用性に ついて検討したので, その結果について報告する.

景観感性設計システムと今回開発手法は，ほぼ同じ結果を示し，手法の有効性が示された。景観感性設 計システムは, アンケートを行うため多大な労力がかかる. しかしながら, オープンデータを用いた手法 は, GISを用いているため比較的簡便に評価が行えるメリットがある.
\end{abstract}

Key Words : open data, GIS, landscape evaluation, Kansei system

\section{1. はじめに}

我が国は，四方を海に囲まれており，美しい砂浜，礫 浜，切り立った岩壁のような多様な海岸線を有している. 一方，海岸線では，台風や冬期波浪といった，厳しい自 然条件にさらされており, 高潮, 津波および浸食等によ る被害軽減を目的とした防護が行われている。

このような, 海岸線の整備にあたって, 国土交通省と 農水省は，海岸景観形成ガイドライン1)策定し，海岸 の整備や取り組みの方向を示した. ガイドラインでは,

「自然環境基盤」(海岸地形 : 砂浜, 岬等), 「生態環 境」(動植物), 「生活環境」(生業, 生活, 文化)の3つの 視座によってとらえる必要があるとされ, 整備や取り組 みの方策が示されている，しかしながら，景観形成にあ たっては，景観の良否を評価するシステムや具体的な設 計手法に関しては，示されていない.

海岸景観評価に関する研究では，写真を提示し得られ たアンケート結果に対し多変量解析を行った方法”や, ニューラルネットワークを用いた方法")，感性工学手法 を用いた方法4, 5), のがある. このように，定量的な景観 評価に関しては様々な試みが行われているものの, 技術 的手法は確立されておらず，実務面では，旧態依然とし
たパース図やCG描画による表現に留まっている.

本研究では，オープンデータをもとにGISを用い，鳥 取県景観マップを作成し, 景観構成指標值から景観指標 值を求め, 筆者らの林開発した景観感性設計システムと 合わせて分析を行い，オープンデータを用いた定量的海 岸評価手法の有用性について検討したので，その結果に ついて報告する.

\section{2. 評価手法の概要}

定量的海岸景観評価手法とは, 海岸景観の質を示す景 観指標值によって評価する手法である，景観指標值は， 景観を構成する複数の構成指標より算出する. 景観構成 指標は，大きく3つの視座の「自然環境基盤」，「生態 環境」および「生活環境」より構成される.さらに各視 座は, 複数の構成指標から成る. 景観の質を示寸景観指 標値は, 複数の景観構成指標を統合したもので, 評価の 対象とする景観の質を，0(低い景観の質)から1(高い景 観の質)で標準化し数值で定量的に表現される.

本評価手法は，野生生物のハビタットの質を表す HSI(Habitat Suitability Index)モデルおよびHSIを算出するた 
めの，複数のSI(Suitable Index)を統合するモデルを参考に 構築した7).

\section{3. 景観マップ}

\section{(1) データ}

オープンデータとは，国，自治体，独立行政法人，公 益事業者が保有する公共データを社会で効率的に利用で きるようにしたデータのことを言う，総務省が定めたオ ープンデータと言える条件は，(1)機械判読に適したデー タ形式，(2)二次利用が可能なルールで公開されたデータ， の2点である ${ }^{8}$.

景観検討に当たっては, 海岸景観形成ガイドラインで,

「自然環境基盤」，「生態環境」，「生活環境」の3つ の視座によって海岸の在り方を考える必要があるとされ ている.

「自然環境基盤」とは，海岸景観のさまざまな成り立 ちを支える天然の基盤であり，砂浜，岬，海域，丘陵等 の海岸地形である1).

「生態環境」とは，その地域に息づく動植物である11.

「生活環境」とは，空間特性・歴史・文化，現在も残 る利用の履歴や人々の記憶である1

オープンデータは，国土交通省では指定地域，自然， 国土骨格等の 7 つの大項目に分かれ，環境省では自然環 境調査の項目別に分かれ，提供されている．特に，環境 省では過去の自然環境調査のデータも公開しており, 変 遷の検討にも活用できる，これらのデータから，先に挙 げた $3 つ の$ 視座に相当する検討対象の鳥取県のデータを 集めた。「自然環境基盤」は「海岸性状」および地形・ 地質等の「自然資源」を，「生態環境」は「巨樹・巨 木」「藻場」「鳥獣保護区」「保安林」「自然公園」を, 「生活環境」は「史跡名勝記念物」「重要文化財」をそ れぞれ景観構成指標として選定した。「生活環境」に関 しては，文化的な空間特性等の利用可能なデータはなく， 全体的に少なく十分ではない.

海岸性状は，「自然海岸」，「半自然海岸」，「人工 海岸」，「河口」に区分した平成 9 ～13年度調查の線デ ータである9.

自然資源は，自然景観の基盤（骨格）を成す地形，地 質および自然景観として認識される自然現象の位置およ び特性に関する情報で，海食崖，海洞，砂丘，岩壁，湖 沼, 火山, 滝, 渓谷等の昭和 $61 \sim 63$ 年度調査の点データ である ${ }^{10}$. データとしては古いが，整備や自然現象で変 化は少ない考えられるため, データとして用いた.

巨樹・巨木は，原則として地上から $1.3 \mathrm{~m} の$ 高さでの幹 周りが3m以上の木を調查対象とし、幹周り $3 \mathrm{~m}$ 以上に育 ちにくい樹種(ツバキ、マユミなど)については、3m未
満も対象とした平成11，12年度調査の点データである ${ }^{11)}$

藻場は，20m以浅の沿岸において，既存調査の結果お よび地元漁業者からの聞き取り等，現状の海藻・海草群 落の位置, 面積の平成 $9 \sim 13$ 年度の面データである ${ }^{12)}$.

鳥獣保護区は，鳥獣の保護繁殖を図るため，鳥獣の保 護および狩猟の適正化に関する法律（鳥獣保護法）に基 づき，必要があると認められる地域を鳥獣保護区に設定 された平成21年度の面データである13).

保安林は，土地利用基本計画に基づき指定された森林 地域について，範囲（面）ならびに当該地域と当該地域 の細区分である「国有林」，「地域森林計画対象民有 林」および「保安林」の平成23年度の面データである ${ }^{14)}$.

自然公園は，自然公園法第2条第1項自然公園（国立公 園、国定公園および都道府県立自然公園）として指定さ れた平成23年度の面データである ${ }^{15)}$.

史跡名勝記念物および重要文化財は, 人文資源（史跡、 社寺，城跡，城郭，庭園，公園，歴史景観，地域景観， 年中行事, 歴史的建築物, 現代建造物, 博物館・美術 館）の中で，文化財種別で史跡名勝記念物と国宝・重要 文化財と区別した平成22年度の点データである ${ }^{16)}$.

\section{(2) 景観マップの作成}

収集したデータは，shapeファイル形式となっており， それらをGISソフト地図太郎に読み込んだ。読み込んだ 後, マップの作成は, 図-1に示すように「自然環境基 盤」をベースマップ，「生態環境」を環境マップ，「生 活環境」を人文マップとしてそれぞれ作成し，それらを 重ねあわせ景観マップとして作成した。

ベースマップの自然環境基盤は，海岸性状を線データ の自然海岸, 半自然海岸, 人工海岸, 河口の4種類と自 然資源の点データにそれぞれ分け作成した.

環境マップの生態環境は，巨樹・巨木，藻場，鳥獣保 護区. 保安林および自然公園にそれぞれ分け作成した.

人文マップの生活環境は, 史跡名勝および国宝・重要 文化財にそれぞれ分け作成した。

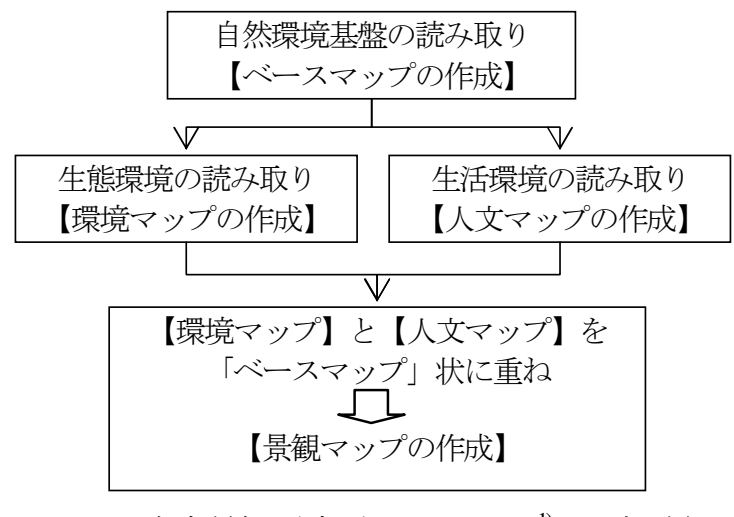

※海岸景観形成ガイドライン ${ }^{1)}$ を部改編

図-1＼cjkstart景観マップ作成の流れ 
図-2は，作成した鳥取県全域の景観マップを示す。鳥 取県内の海岸線近傍では，中部および東部にかけて点デ 一タが集中していることが分かる。また，海岸性状は， 中部〜東部は自然海岸が多い。一方，西部は半自然海岸 もしくは人工海岸が多いことが分かる．海岸線図中の赤 点線は，海岸線から1,500m(近景域および中景域までの 範囲)のラインであり，評価エリアの目安とした。

\section{4. 景観指標と海岸景観評価}

景観評価を行う際，景観域は，視点場から500m程度 の近景域, $500 \mathrm{~m} \sim 1,500 \mathrm{~m}$ 程度の中景域， $1,500 \mathrm{~m}$ 以上の遠 景域に分けられる1).

本研究では，得られたデータは県全域にわたり内陸部 のデータも有するため, 海岸線から $1,500 \mathrm{~m} の$ 中景域まで のデータを対象とし，海岸景観評価に用いた。

\section{(1) 景観構成指標の数値化}

景観構成指標の数值は，表-1 に示すように，構成指 標の状態により点数化を行った，海岸性状は，自然海岸

に点数 $1.0 を ，$ 半自然海岸に 0.75 , 人工海岸に 0.50 点数を 与え，その差は0.5とした．筆者らのこれまでの研究で ${ }^{17)}$ ， 都市のウォーターフロントのように調和の取れている海 岸の場合，自然海岸より評価が高い場合があるため，そ の差は0.5と, 他の構成指標の差0.9に比べ小さくした. 他の構成指標はその有無で点数をつけた. なお, 藻場,

表-1 景観構成指標の数值化

\begin{tabular}{|c|c|c|c|c|c|c|c|}
\hline 視座 & 構成指標 & 状態 & 点数 & 状態 & 点数 & 状態 & 点数 \\
\hline \multirow{2}{*}{$\begin{array}{l}\text { 自然環境 } \\
\text { 基盤 }\end{array}$} & 海岸性状 & 自然海岸 & 1.0 & 半自然海岸 & 0.8 & 人工海岸 & 0.5 \\
\hline & 自然資源 & 有り (3つ以上) & 1.0 & 有り $(1 \sim 2)$ & 0.8 & なし & 0.1 \\
\hline \multirow{5}{*}{ 生態環境 } & 巨樹·巨木 & 有り(3つ以上) & 1.0 & 有り $(1 \sim 2)$ & 0.8 & なし & 0.1 \\
\hline & 藻場 & \begin{tabular}{|c|} 
有り \\
$(3000 \mathrm{~m}$ 以上 $)$ \\
\end{tabular} & 1.0 & $\begin{array}{c}\text { 有り } \\
(3000 \mathrm{~m} \text { 未満 }) \\
\end{array}$ & 0.8 & なし & 0.1 \\
\hline & 鳥獣保護区 & \begin{tabular}{|c|} 
有り \\
$(3000 \mathrm{~m}$ 以上 $)$ \\
\end{tabular} & 1.0 & $\begin{array}{c}\text { 有り } \\
(3000 \mathrm{~m} \text { 未満 }) \\
\end{array}$ & 0.8 & なし & 0.1 \\
\hline & 保安林 & \begin{tabular}{|c|} 
有り \\
$(3000 \mathrm{~m}$ 以上 $)$ \\
\end{tabular} & 1.0 & $\begin{array}{c}\text { 有り } \\
(3000 \mathrm{~m} \text { 未満 }) \\
\end{array}$ & 0.8 & なし & 0.1 \\
\hline & 自然公園 & \begin{tabular}{|c|} 
有り \\
$(3000 \mathrm{~m}$ 以上 $)$ \\
\end{tabular} & 1.0 & $\begin{array}{c}\text { 有り } \\
(3000 \mathrm{~m} \text { 未満 }) \\
\end{array}$ & 0.8 & なし & 0.1 \\
\hline \multirow{2}{*}{ 生活環境 } & \begin{tabular}{|l} 
史跡・名勝 \\
記念物
\end{tabular} & 有り (3つ以上) & 1.0 & 有り $(1 \sim 2)$ & 0.8 & なし & 0.1 \\
\hline & 重要文化財 & 有り (3つ以上) & 1.0 & 有り $(1 \sim 2)$ & 0.8 & なし & 0.1 \\
\hline
\end{tabular}

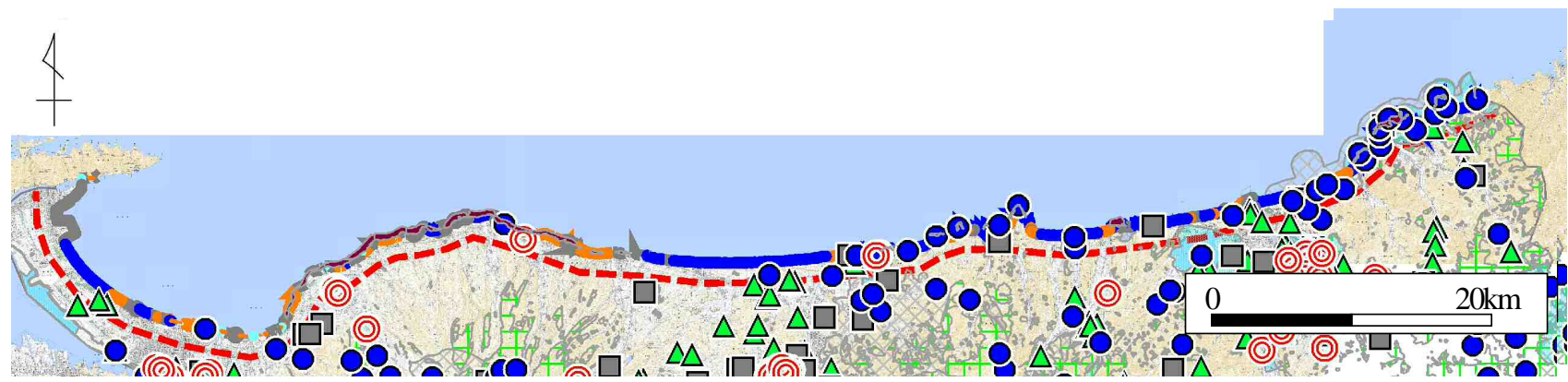

図-2 景観マップ

※凡例

点 ○自然資源， $\Delta$ 巨樹・巨木， 史跡名勝記念物，国宝・文化財

線 海岸性状( 一自然海岸, 一半自然海岸, 一人工海岸), ‥海岸線加ら $1,500 \mathrm{~m}$

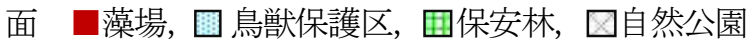

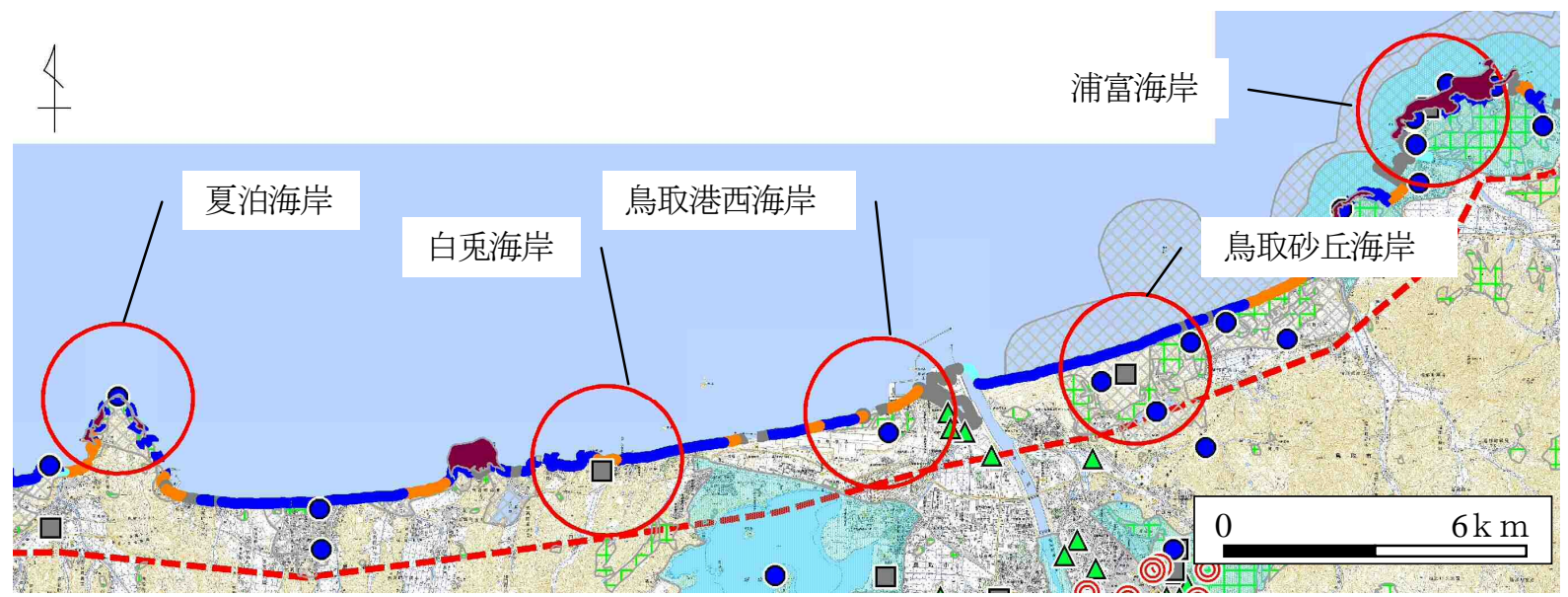

図-3＼cjkstart景観マップからの抽出エリア

$※$ 凡例

赤線内抽出エリア，点 ○自然資源， $\Delta$ 巨樹・巨木，匹史跡名勝記念物，国宝・文化財

線 海岸性状(一自然海岸，一半自然海岸，一人工海岸)，‥海岸線加 1,500m

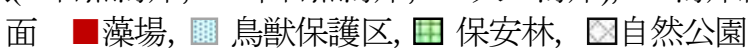


鳥獣保護区，保安林，自然公園は，有りの場合でも，後 に抽出するエリア内の海岸線に沿った総延長 $3,000 \mathrm{~m}$ (エ リア中心から中景域までの1,500mの2倍)で差をつけた.

海岸景観評価のための景観指標の数值化は，鳥取県の 海岸域全域について行うのではなく, 検討のために景観 マップより構成指標の重なりぐあいを判読し，図-3に示 すような代表的な半径 $1,500 \mathrm{~m}$ の等距離円エリア5 方所を 抽出し行った.

各抽出エリア海岸の特徴は以下に示す.

浦富海岸は, 自然海岸で, 自然資源や史跡名勝記念物, 藻場，鳥獣保護区，保安林，自然公園を有する.

鳥取砂丘海岸は, 自然海岸で, 自然資源や史跡名勝記 念物，保安林，自然公園を有する.

鳥取港西海岸は，大半が半自然海岸で，自然資源，保 安林を有する.

白鬼海岸は，一部半自然海岸で，史跡名勝記念物，小 規模の保安林を有する.

夏泊海岸は，自然海岸で，史跡名勝記念物，藻場，保 安林を有する.

表-2は，景観構成指標の状態から抽出エリア内の数值 化を行った結果を示す。ここで，海岸性状は，範囲内の 自然海岸，半自然海岸，人工海岸をGISの検索機能を活 用して抽出し，それぞれに各点数を掛け合わせて合計值 を算出した．自然資源，巨樹・巨木，史跡名勝記念物お よび重要文化財は，エリア内のデータの有無で点数を算 出した。藻場, 鳥獣保護区, 保安林および自然公園は, 海岸線に沿った総延長をGISの距離測定機能を用いて求 め点数を算出した.

\section{(2) 景観指標の数値化}

景観指標の数值化は, まず3つの視座の重みを求め, 景観構成指標值の結合式から景観指標を求め海岸景観評 価を行った.

3つの視座の重みづけは，評価基準の重みづけの算出 に特徵のあるAHP(Analytic Hierarchy Process)を用いた。な お，重みづけは，海岸の専門家5名に対して行った一対

表-2＼cjkstart抽出エリアの景観構成指標値

\begin{tabular}{l|l|r|r|r|r|r}
\hline 視座 & 構成要素 & 浦富 & 鳥取砂丘 & 鳥取港西 & 白鬼 & 夏泊 \\
\hline \hline \multirow{2}{*}{$\begin{array}{l}\text { 自然環境 } \\
\text { 基盤 }\end{array}$} & 海岸性状 & 0.64 & 0.93 & 0.27 & 0.98 & 0.93 \\
\cline { 2 - 8 } & 自然資源 & 1.00 & 0.75 & 0.75 & 0.10 & 0.75 \\
\hline \multirow{4}{*}{ 生態環境 } & 巨樹·巨木 & 0.10 & 0.10 & 1.00 & 0.10 & 0.10 \\
\cline { 2 - 8 } & 藻場 & 0.75 & 0.10 & 0.10 & 0.10 & 0.75 \\
\cline { 2 - 8 } & 鳥獣保護区 & 1.00 & 0.10 & 0.10 & 0.10 & 0.10 \\
\cline { 2 - 8 } & 保安林 & 0.75 & 1.00 & 0.75 & 0.75 & 0.75 \\
\cline { 2 - 8 } & 自然公園 & 1.00 & 1.00 & 0.10 & 0.10 & 1.00 \\
\hline \multirow{3}{*}{ 生活環境 } & 史跡名勝記念物 & 0.75 & 0.75 & 0.10 & 0.75 & 0.10 \\
\cline { 2 - 8 } & 国宝·文化財等 & 0.10 & 0.10 & 0.10 & 0.10 & 0.10 \\
\hline
\end{tabular}

比較のアンケートをもとに算出した．その結果，重みは， 自然環境基盤が 0.45 , 生態環境が 0.32 , 生活環境が 0.23 と なり，自然環境基盤が高い值となった。 ベースマップと なる自然環境基盤が高く，次いで生態環境で，海岸の専 門家としての特徵が表れていると考えられる.

各視座の構成要素に重みを掛け合わせ求めた重みづけ 景観構成指標値と景観指標值を表-3に示寸，景観指標値 は, 各視座の構成要素数が異なるため, 相加平均值とし た.

景観指標の数值化は，相加平均法，相乗平均法，限定 要因法，加算要因法などがある，その作成にあたって， 結合式の決定などには明確な数学的理論はない，そこで， 景観評価に適切と考えられる, 相加平均法と相乗平均法 について検討を行い，相加平均法を用いた，その結果， 浦富海岸が0.232 と最も高い值となり, 次いで鳥取砂丘 海岸の0.187，夏泊海岸の0.185，鳥取港西海岸の0.129, 白兔海岸の0.117となった。

\section{5. 評価手法の検討}

本研究でのオープンデータを用いた海岸景観評価手 法を検証するために，筆者らが開発した景観感性設計シ ステムを用い検証を行った.

\section{（1）景観感性設計システムの概要}

景観感性設計システムは，海岸景観写真の印象を問う ワードにSD (Semantic defferential) 法を用い評価を行い，次 にその評価点を目的変数とし, 海岸景観の構成要素 (ア イテムとカテゴリー)を説明変数とし, 数量化理論 I 類 により分析を行い構築したものである. ある海岸景観の 構成要素 (説明変数)を選択寸ると, 形容詞毎の評価点 (目的変数)を算出できる ${ }^{6}$.

具体的には同システムは，海岸景観の写真を見ながら， 写真の印象を表すワードを選択し，表-4に示すような画

表-3 重みづけ景観構成指標值と景観指標値

\begin{tabular}{|c|c|c|c|c|c|c|}
\hline 視座 & 構成要素 & 浦富 & 鳥取砂丘 & 鳥取港西 & 白兔 & 夏泊 \\
\hline \multirow{2}{*}{$\begin{array}{l}\text { 自然環境 } \\
\text { 基盤 }\end{array}$} & 海岸性状 & 0.287 & 0.418 & 0.121 & 0.441 & 0.419 \\
\hline & 自然資源 & 0.450 & 0.338 & 0.338 & 0.045 & 0.338 \\
\hline \multirow{5}{*}{ 生態環境 } & 巨樹·巨木 & 0.032 & 0.032 & 0.320 & 0.032 & 0.032 \\
\hline & 藻場 & 0.240 & 0.032 & 0.032 & 0.032 & 0.240 \\
\hline & 鳥獣保護区 & 0.320 & 0.032 & 0.032 & 0.032 & 0.032 \\
\hline & 保安林 & 0.240 & 0.320 & 0.240 & 0.240 & 0.240 \\
\hline & 自然公園 & 0.320 & 0.320 & 0.032 & 0.032 & 0.320 \\
\hline \multirow{2}{*}{ 生活環境 } & 史跡名勝記念物 & 0.173 & 0.173 & 0.023 & 0.173 & 0.023 \\
\hline & 国宝·文化財等 & 0.023 & 0.023 & 0.023 & 0.023 & 0.023 \\
\hline \multicolumn{2}{|c|}{ 景観指標値 } & 0.232 & 0.187 & 0.129 & 0.117 & 0.185 \\
\hline
\end{tabular}


面上で，各アイテム・カテゴリーのラジオボタンを選択 することで，0１00の評価点が算出される. 同システム を用い，図-3に示す抽出したエリア内で，撮影した図-4 に示すような写真をもとに，海岸景観の印象ワードを調 和性とし評価点を算出した，写真を用いた評価は，撮影 対象に依存するが，景観写真では一般的に近景から遠景 までを含むのが特徴である.

\section{(2) 検討結果}

オープンデータを用いた海岸景観指標值と景観感性設 計システム算出值を比較した結果を表-5に示す.

オープンデータを用いた海岸景観指標值と景観感性設 計システムによる算出值ともに，浦富海岸が点数が高く， 次いで鳥取砂丘海岸が高いことがわかる. 最も低い点数 の海岸は白兔海岸，鳥取港西海岸と異なっていた。

表-6は，オープンデータを用いた海岸景観指標值と景 観感性設計システム算出值の海岸別のランキングを示す オープンデータを用いた海岸景観指標值と景観感性設計 システム算出值ともに，上位から浦富海岸，鳥取砂丘海

表-4＼cjkstart景観感性設計システムの画面の項目

\begin{tabular}{l|l}
\hline アイテム & カテゴリー \\
\hline 海岸線形状 & ○直線的 ○曲線的 \\
\hline 護岸の種類 & ○階段護岸 ○傾斜(緩) ○波消工 \\
\hline ○直立 ○突堤 ○自然海岸
\end{tabular}
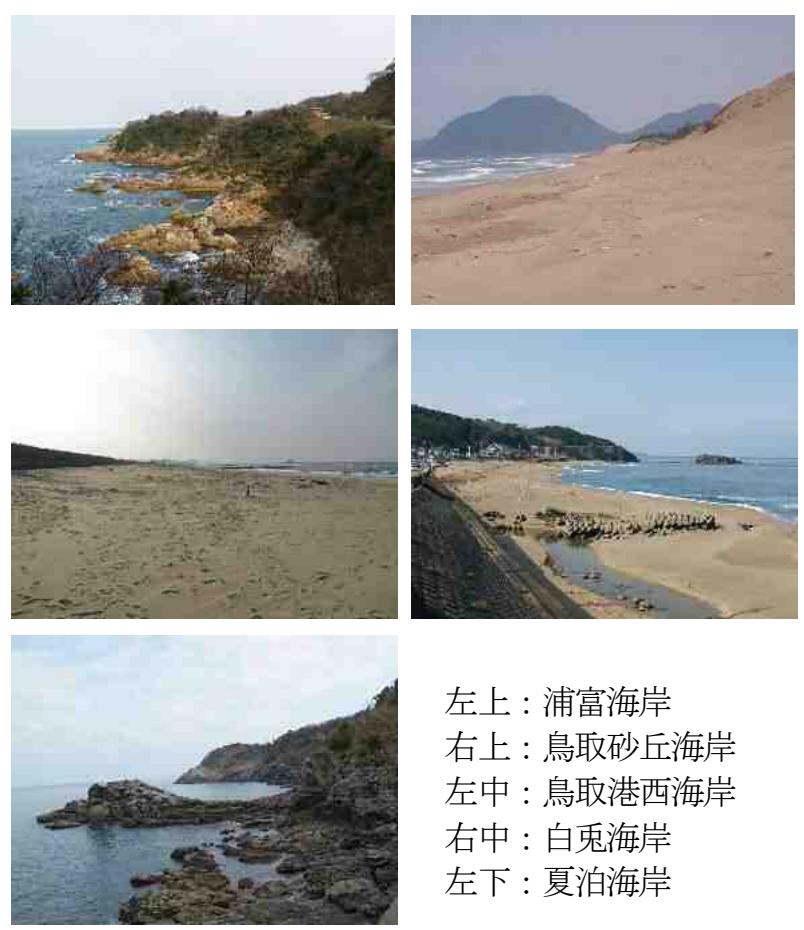

左上 : 浦富海岸 右上 : 鳥取砂丘海岸 左中：鳥取港西海岸 右中 : 白兔海岸 左下 : 夏泊海岸

図-4＼cjkstart景観感性設計システムに用いた写真
岸，夏泊海岸となったが，鳥取西港海岸と白兔海岸では 順位が逆になった。

順位4，5位について検討してみる．表-2から，鳥取港 西海岸と白兔海岸の景観構成指標値をみると，海岸性状 と史跡名勝記念物で白兔海岸が高く, 自然資源と巨樹・ 巨木で鳥取港西海岸が高くなっている.

「自然環境基盤」の鳥取港西海岸の合計值は1.02で, 白兔海岸の合計值は1.08で，その差は0.06で白兔海岸が 高かった.「生態環境」の鳥取港西海岸と白兔海岸は, 巨樹・巨木だけが異なり，その差は0.9で鳥取港西海岸 が高かった.「生活環境」の鳥取港西海岸と白兔海岸は, 史跡名勝記念物が異なり，その差は0.65で白兔海岸が高 かった. 鳥取港西海岸は0.29景観構成指標において白兔 海岸より高い結果となった，景観指標值は，さらに重み を掛け算出するが，重みの高い「自然環境基盤」で景観 構成指標值の差が小さく影響は小さい. しかしながら, 景観構成指標值の差が最も大きく，重みが次いで大きい 生態環境で影響が大きくなった。この差を，生活環境の 景観構成指標との重みより，埋めることはできなかった。

このように，景観構成指標の状態から数值化する際の 閾值の影響や重み付けが景観指標值に影響を及ぼしてい ることがわかる。その結果，各手法によりランキングが 異なったことが考えられる. 景観構成指標の状態から数 值化を行うに当たっては，多くの海岸で検証を行い，更 なる検討が必要である.

また，各手法によりランキングが異なったさらなる理 由は，オープンデータを用いた海岸景観評価では，半径 $1,500 \mathrm{~m}$ の等距離円内の様々な地域資源を抽出している が，景観設計システムでは写真に写る視距離に依存して おり，地形によっては数キロに及ぶこともあるため地域 資源の抽出に大きな違いがあることも要因と考えられる.

各手法でランキングは，一部異なったものの，地域資 源を抽出し海岸を評価する手法としては，オープンデー

表-5＼cjkstart各手法による值

\begin{tabular}{c|c|c}
\hline $\begin{array}{c}\text { エリア } \\
\text { 番号 }\end{array}$ & $\begin{array}{c}\text { オープンデータを用いた } \\
\text { 海岸景観指標值 }\end{array}$ & $\begin{array}{c}\text { 景観感性設計システム } \\
\text { 算出值 }\end{array}$ \\
\hline \hline 浦富海岸 & 0.232 & 75.81 \\
\hline 鳥取砂丘海岸 & 0.187 & 68.39 \\
\hline 鳥取港西海岸 & 0.129 & 44.58 \\
\hline 白鬼海岸 & 0.117 & 55.31 \\
\hline 夏泊海岸 & 0.185 & 68.03 \\
\hline
\end{tabular}

表-6 各手法によるランキング

\begin{tabular}{r|c|c}
\hline 順位 & $\begin{array}{c}\text { オープンデータを用いた } \\
\text { 海岸景観指標值 }\end{array}$ & $\begin{array}{c}\text { 景観感性設計システム } \\
\text { 算出值 }\end{array}$ \\
\hline \hline 1 & 浦富海岸 & 浦富海岸 \\
\hline 2 & 鳥取砂丘海岸 & 鳥取砂丘海岸 \\
\hline 3 & 夏泊海岸 & 夏泊海岸 \\
\hline 5 & 鳥取港西海岸 & 白鬼海岸 \\
\hline 崖鬼海岸 & 鳥取港西海岸 \\
\hline
\end{tabular}


タを用いた手法は有効であることが伺える．また，景観 感性設計システムは，アンケートを行うため多大な労力 がかかるが，オープンデータを用いた手法は比較的簡便 に評価が行える.

\section{6. おわりに}

本研究は，オープンデータをもとにGISを用い，鳥取 県景観マップを作成し，景観構成指標から景観指標を求 め，景観感性設計システムと合わせて分析を行い，同評 価方法の有用性について検討したので，その結果につい て報告する。

オープンデータは，(1)機械判読に適したデータ形式, (2)二次利用が可能なルールで公開されたデータのため地 域資源の抽出に有効であり, 地域資源を景観構成指標と して指標化することによって比較的簡便に評価が行える メリットがある.

また，景観感性設計システムと合わせて分析を行った 結果はほぼ一致するような結果となった。

しかしながら，オープンデータを用い，景観構成指標 の状態から数值化を行うにあたっては，多くの海岸で検 証を行い, さらなる検討が必要である.

\section{参考文献}

1）国土交通省河川局・港湾局，農林水産省農林振興 局・水産庁：海岸景観形成ガイドライン, $134 \mathrm{p}$, 2006.

2) 中園眞人, 石川貴士, 内田唯史, 岩本慎二, 浮田正 夫 : 博多湾における海岸域の景観評価構造に関する 研究, 山口大学工学部報告, vol.44, No.2, pp.63-71, 1994.

3）永瀬恭一, 松原雄平, 野田英明 : ニューラルネット ワークを利用した海岸景観の評価に関寸る研究, 海 岸工学論文集, 第 45 巻, pp.1206-1210, 1998.
4) 熊谷健蔵, 松原雄平 : 感性工学的手法による海岸景 観評価に関する研究, 海岸工学論文集, 第 48 巻, pp.1326-1330， 2001.

5）松原雄平, 犬山正, 山形浩一, 市村康, 磯打千雅 子 : 海岸景観評価システムの確立に関する研究, 海 岸工学論文集, 第 52 巻, pp.1231-1235, 2005.

6) 松原雄平, 市村康, 小泉知義 : 海岸景観向上のため の感性設計システムの開発と活用に関する検討, 海 岸工学論文集，第 54 巻, pp.1306-1310, 2007.

7) 田中章: 生物多様性保全のための戦略的環境アセス メント手法 HEP 入門, 266p, 朝倉書店, 2011 .

8）総務省：http://www.soumu.go.jp/menu_seisaku/ ictseisaku/ictriyou/opendata/opendata01.html

9) 環境省自然環境局生物多様性センター：自然環境 GIS 提供システム, 海岸改変状況調査, http://www.biodic.go.jp/trialSystem/kg/kg.html.

10）国土交通省国土政策局国土情報課：国土数值情報地 域資源データ，国土数值情報ダウンロードサービス， http://nlftp.mlit.go.jp/ksj/gml/datalist/KsjTmplt-P19.html .

11）環境省自然環境局生物多様性センター：巨樹・巨木 調査, 自然環境 GIS 提供システム, http://www.biodic.go.jp/trialSystem/info/big.html.

12) 環境省自然環境局生物多様性センター：藻場調査, 自 然環 境 GIS 提 供シ人テム, http://www.biodic.go.jp/trialSystem/info/mo.html.

13）環境省自然環境局生物多様性センター：国指定鳥獣 保護区区域等, 自然環境 GIS 提供システム, http://www.biodic.go.jp/trialSystem/info/nwp.html.

14）国土交通省国土政策局国土情報課：国土数值情報森 林地域データ国土数值情報ダウンロードサービス， http://nlftp.mlit.go.jp/ksj/gml/datalist/KsjTmplt-A13.html .

15）国土交通省国土政策局国土情報課：国土数值情報自 然公園地域データ，国土数值情報ダウンロードサー ビ ス , http://nlftp.mlit.go.jp/ksj/gml/datalist/KsjTmpltA10-v3_1.html.

16）国土交通省国土政策局国土情報課：文化財，国土数 值情報ダウンロードサービス， http://nlftp.mlit.go.jp/ksj/gmlold/cgi-bin/_area_view.cgi.

17) 市村康, 松原雄平 : 感性工学手法による海岸景観評 価について, 環境アセスメント学会 2006 年研究発表 会要旨集, pp.217-222,, 2006.

\section{STUDY ON QUANTITATIVE COASTAL LANDSCAPE EVALUATION METHOD USING OPEN DATA}

\section{Yasushi ICHIMURA, Yuhei MATSUBARA and Kotaro GOTO}

In this study, we made a landscape map of Tottori Prefecture using the open data, and determined the landscape indicator from landscape composition index. Next, we analyzed the new quantitative coastal landscape evaluation method by comparing the landscape design system, and would like to report the results.

According to the analysis, the new evaluation method and the landscape design system showed nearly identical results. Consequently, it demonstrated the effectiveness of the new method.

The landscape design system needs a large amount of energy to have questionnaire survey. In contrast, the new evaluation method by using the open data has an advantage which is easy to conduct by the use of GIS. 